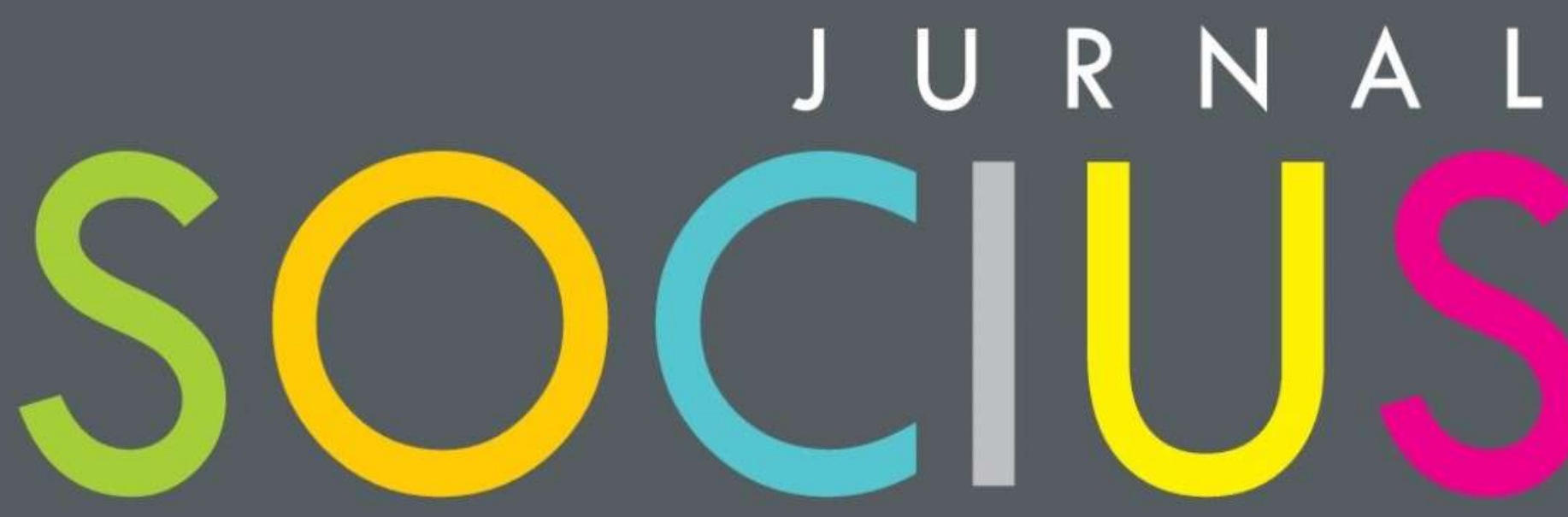

Journal of Sociology Research and Education

DITERBITKAN OLEH :

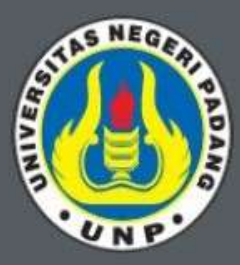

LABOR JURUSAN SOSIOLOGI FAKULTAS ILMU SOSIAL UNIVERSITAS NEGERI PADANG

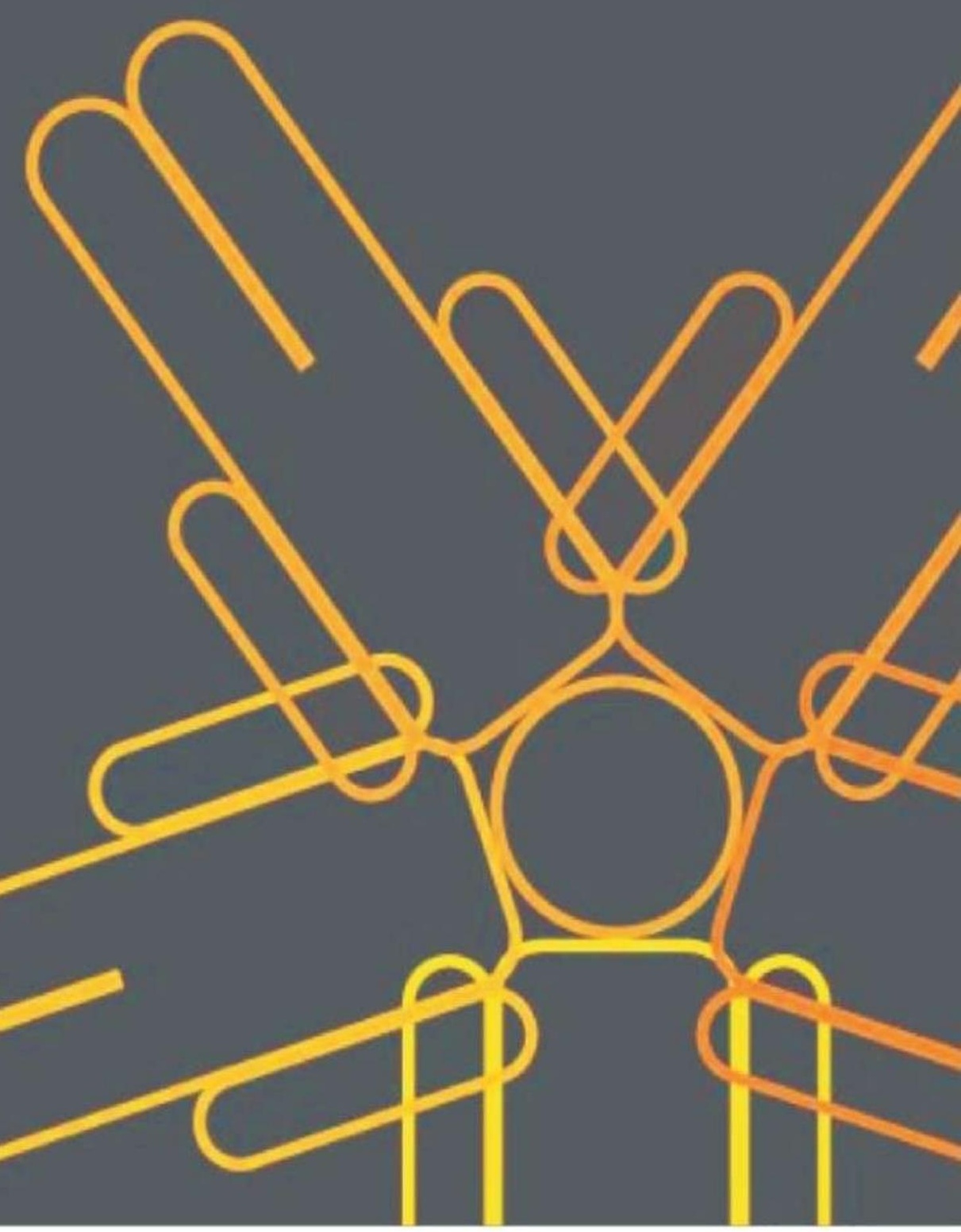




\section{SOCIUS}

Vol. 4, No.1, Th. 2017

ISSN: 2356-4180 (cetak)

2442-8663 (online)

REDAKSI JURNAL SOCIUS

Ketua Dewan Penyunting : Dr. Erianjoni, S.Sos., M.Si

Wakil Ketua Dewan Penyunting : Selinaswati, S.Sos., M.A., Ph.D.

\section{Dewan Penasehat:} Prof. Dr. Syafri Anwar, M.Pd (Universitas Negeri Padang) Prof. Dr. Mestika Zed, MA. (Universitas Negeri Padang) Prof. Dasman Lanin, M.Pd., Ph. D. (Universitas Negeri Padang) Bakhrul Khair Amal, SE.,M.Si. (Universitas Negeri Medan)

Prof. Dr. Ferdinand Kerebungu, M.Si. (Universitas Negeri Manado) Dr.rer.nat. Nurhadi, S.Ant., M. Hum. (Universitas Negeri Solo)

Drs. Emizal Amri, M.Pd., M.Si. (Universitas Negeri Padang) Adri Febrianto, S.Sos., M.Si. (Universitas Negeri Padang) Drs. Ikhwan, M.Si. (Universitas Negeri Padang)

Dewan Penyunting:

Dr. EkaVidya Putra,S.Sos,.M.Si. Dr. Desy Mardiah,S.Sos.,S.Thi,.M.Si Ike Sylvia, S.IP,.M.Si

M. Isa Gautama,S.Pd,.M.Si. Reno Fernandes, S.Pd.,M.Pd.

\section{Layout Editor:}

Rhavy Ferdyan, S.Pd.

Technical Support:

Rudi Mahesa, A.Md.

Alamat Redaksi:

Jurusan Sosiologi FIS UNP

Jl. Prof.Dr.Hamka

Kampus UNP Air Tawar

e-mail: sosan@fis.unp.ac.id

\section{Penerbit}

Labor Jurusan Sosiologi

Universitas Negeri Padang
Artikel :

\section{DAFTAR ISI}

\section{Eka Vidya Putra}

Money Politics Dalam Penyelengaran Pemilihan Umum

Di Kota Pariaman

Halaman 1-16

Helpi Nelwatri

Upaya Preventif Masalah Kesehatan Reproduksi Remaja Melalui Media Informatif Buku Saku Kespro

Berbasis Budaya Lokal Untuk Orang Tua

Di Kabupaten Lima Puluh Kota

Provinsi Sumatera Barat

Halaman 17-21

\section{Junaidi}

Upaya Meningkatkan Kemampuan Peserta Didik Berpikir Kritis

Melalui Penerapan Srategi Pembelajaran Berbasis Masalah

Pada Pembelajaran Sosiologi Kelas XI IPS 2 SMA Negeri 1 Pariaman Halaman 22-30

Muhammad Hidayat

Problematika Internal Nelayan Tradisional KotaPadang:Studi FaktorFaktor Sosial Budaya Penyebab Kemiskinan

$$
\text { Halaman 31-40 }
$$

Mohammad Isa Gautama

Analisis Framing Pemberitaan Operasi Tangkap Tangan Patrialis Akbar

Di Media Daring Lokal Dan Nasional Halaman 41-49

\section{Nurlizawati}

Perceraian Secara Adat (Cerai Dusun)

Halaman 50-60 


\title{
UPAYA MENINGKATKAN KEMAMPUAN PESERTA DIDIK BERPIKIR KRITIS MELALUI PENERAPAN SRATEGI PEMBELAJARAN BERBASIS MASALAH PADA PEMBELAJARAN SOSIOLOGI KELAS XI IPS 2 SMA NEGERI 1 PARIAMAN
}

\author{
Deri Indrahadi ${ }^{1}$, Junaidi ${ }^{2}$ \\ 1,2 Universitas Negeri Padang \\ Email: junaidisatir@gmail.com
}

\begin{abstract}
Abstrak
Pembelajaran sosiologi di sekolah tidak hanya memberi tekanan pada pemahaman tetapi membentuk kemampuan berpikir kritis peserta didik. Penelitian ini bertujuan untuk mengetahui peningkatan kemampuan berpikir kritis pada peserta didik kelas XI IPS 2 SMA Negeri 1 Pariaman dengan menerapkan strategipembelajaran berbasis masalah. Penelitian ini terdiri atas dua siklus. Instrumen penelitian berupa lembar observasi, catatan lapangan dan wawancara. Data dianalisis dengan menggunakan teknik analisis deskriptif persentase. Hasil penelitian mengungkapkan bahwa prosespembelajaran yang dilakukan dengan strategi pembelajaran berbasis masalah dapat meningkatkan kemampuan berpikir kritis peserta didik.
\end{abstract}

Kata Kunci: Kemampuan berpikir kritis, Pembelajaran berbasis masalah, Sekolah, Sosiologi

\begin{abstract}
Learning sociology at school is not only to make student understand about the topics but it also to shapes the critical thinking ability of students. This study aims to know more detail the improvement of critical thinking ability of class XI IPS 2 SMA Negeri 1 Pariaman by applying problem-based learning strategy. This study is quantitates research in which the data consists of observation sheets, field notes and interviews. Data analysis using descriptive analysis technique percentage. The results of research revealed the learning process conducted withproblem-based learning strategy can improve the critical thinking ability of learners.
\end{abstract}

Keywords: Critical thinking ability, Problem-based learning, School, Sociology

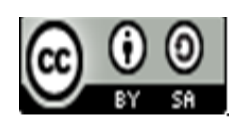

\section{Pendahuluan}

Sosiologi adalah satu di antara mata pelajaran di lembaga pendidikan Sekolah Menengah Atas (SMA) memiliki peran penting yang berusaha mengembangkan pemahaman peserta didik terhadap konsep dan fenomena sosial yang terjadi dalam kehidupan sehari hari. Dengan adanya pemahaman maka peserta didik diharapkan dapat memiliki kemampuan untuk menghadapi dan menyelesaikan berbagai masalah sosial yang ditemuinya dalam kehidupan sehari-hari.

Salah satu kemampuan pendukung dalam menghadapi permasalahan sosial adalah kemampuan berfikir kritis. Pembelajaran sosiologi menuntut kemampuan berfikir kritis dari peserta didik. Pada kenyataannya kemampuan kritis ini belum begitu terlihat pada peserta didik. Kenyataan ini dapat diketahui darihasil pengamatan yang dilakukan di kelas XI IPS 2 SMA Negeri 1 Pariaman pada Tahun Pelajaran 2016-2017. Dari 32 orang peserta didik hanya 
7 orang yang sering memberikan pertanyaan dan memberi tanggapan pada saat pembelajaran berlangsung. Kemampuan berfikir kritis mereka dapat dilihat pada tabel di bawah ini.

Tabel 1. Kemampuan Berpikir Kritis dalam Pembelajaran Sosiologi Pada Peserta Didik Kelas XI IPS 2 SMAN 1 Pariaman

\begin{tabular}{cllc}
\hline \multirow{2}{*}{ No } & \multicolumn{1}{c}{ Kemampuan Berpikir Krtitis Peserta Didik } & \multicolumn{2}{c}{ Observasi } \\
\cline { 3 - 4 } & \multicolumn{2}{c}{ J $=32$} \\
\hline 1 & $\begin{array}{l}\text { Mengidentifikasi bebapa contoh konflik yang disajikan } \\
\text { guru, peserta didik menentukan konflik tersebut termasuk } \\
\text { ke dalam salah satu bentuk konflik }\end{array}$ & 4 & $12,5 \%$ \\
\hline 2 & $\begin{array}{l}\text { Memberikan pertanyaan secara tepat (pertanyaan kritis) } \\
\text { terkait contoh konflik yang disajikan guru }\end{array}$ & 3 & $9,37 \%$ \\
\hline 3 & $\begin{array}{l}\text { Mengemukakan pendapat atau asumsi yang diketahui } \\
\text { peserta didik terkait dengan contoh konflik yang disajikan } \\
\text { guru }\end{array}$ & 4 & $125 \%$ \\
\hline 4 & $\begin{array}{l}\text { Menentukan solusi permasalahan yang terdapat selama } \\
\text { proses pembelajaran }\end{array}$ & 5 & $15,6 \%$ \\
\hline 5 & $\begin{array}{l}\text { Mengemukakan solusi dari permasalahan terkait contoh } \\
\text { konflik yang disajikan guru }\end{array}$ & 5 & $15,6 \%$ \\
\hline 6 & $\begin{array}{l}\text { Menentukan kesimpulan dari solusi permasalahan dalam } \\
\text { pembelajaran bentuk-bentuk konflik }\end{array}$ & 1 & $3,12 \%$ \\
\hline & Rata-rata & 4 & $12,5 \%$ \\
\hline
\end{tabular}

Sumber: Olahan Hasil observasi pembelajaran sosiologi kelas materi Bentuk-entuk Koflik,2017.

Data di atas menunjukkan bahwa kemampuan berpikir kritis peserta didikmasih berkategori sangat rendah,terutama indikator kemampuan membuat kesimpulan untuk solusi permasalahan.

Peneliti melihat bahwa rendahnya kemampuan berpikir kritis peserta didik disebabkan oleh beberapa faktor terutama dari guru itu sendiri. Guru belum mampu menentukan model pembalajaran yang tepat untuk materi pembelajaran yang diajarkan dan juga guru lebih banyak mendominasi selama proses pembelajaran. Kemudian dari peserta didik itu sendiri mereka tidak dibiasakan untuk bertanya, memberikan pendapat, menemukan solusi masalah bahkan untuk menyimpulkan pembelajaran.

Pembelajaran yang didasarkan pada suatu masalah yang nyata merupakan salah satu strategi pembelajaran yang dilakukan guru untuk merangsang peserta didikberpikir tingkat tinggi dalam situasi yang benar-benar terjadi dalam kehidupan, termasuk di dalamnya peserta didik belajar tentang bagaimana seharusnya belajar. ${ }^{1} \mathrm{Jadi}$, pembalajaran berbasis masalah bisa dikatakan sebagai suatu strategi pembelajaran yang memanfaatkan masalah-masalah nyata sebagai sebuah sarana bagi peserta didik untuk belajar bagaimana berpikir secara kritis dalam rangka menumbuhkan keterampilan memecahkan masalah, yang otomatis memperoleh pengetahuan dan konsep materi pembelajaran.

Proses pembelajaran yang terlaksana melalui sebuah masalah merupakan strategi yang dipercaya efektif untuk membentuk proses berpikir tingkat tinggi. Melalui strategi ini peserta didik dibantu mengolah bebrbagai imformasi yang sudah terbentuk di dalam pikirannya.

${ }^{1}$ M. Ibrahim dan M. Nur. 2000. Pembelajaran Kooperatif.Surabaya: University Press. Hal. 2 
Mereka diberikan kesempatan menyusun pengetahuan sendiri tentang dunia sosial dan lainnya yang ada di sekitar di mana mereka berada. Strategi pembelajaran ini sangat cocok digunakan untuk mengembangkan pengetahuan baik yang dasar maupun kompleks. ${ }^{2}$

\section{Kajian Teori}

\section{Pembelajaran}

Pembelajaran merupakan suatu kegiatan interaksi yang dilakukan peserta didik dengan lingkungannya, yang mengakibatkan terjadi perubahan ke arahyang diinginkan. ${ }^{3}$ Sugihartono, menyatakan pembelajaran adalah serangkaian upaya yang dilakukan secara sengaja oleh guru sebagai pendidik untuk menyampaikan ilmu pengetahuan, dengan caramengorganisir, dan menciptakan sistemlingkungan melalaui metode yang tepat. Dengan demikian peserta didik dapat melakukan kegiatan belajar secara efektif, efisien serta memperoleh hasil yang optimal. $^{4}$

\section{Berfikir Kritis}

Trianto, menyatakan berpikir adalah kegiatan otak dalam menganalisis, mengkritik, hingga memperoleh kesimpulan berdasakanr berbagai inferensi atau pertimbangan yang seksama. ${ }^{5}$ Menurut John Dewey, secara esensial berpikir kritis merupakan aktivitas seseorang yang memikirkan berbagai hal secara mendalam, membuat pertanyaan untuk dijawab sendiri, menemukan dan mencari informasi yang relevan untuk diri sendiri. Dia lebih mengutamakan usaha sendiri daripadamenerimanya hal dari orang lain. ${ }^{6}$

Indikator berpikir kritis menurut Fisher ${ }^{7}$, antara lain adalah:

a. Memberikan penjelasan mendasar dengan sub indikator: mengidentifikasi pokok masalah dan memberikan pertanyaan secara tepat (pertanyaan kritis)

b. Memberikan penjelasan lanjut dengan sub indikator: mengidentifikasi asusmsi

c. Kemampuan dalam penyelesaian permasalahan dengan sub indikator: menentukan solusi permasalahan dan mengemukakan solusi dari permasalahan

d. Kemampuan menyimpulkan dengan sub indikator: menentukan kesimpulan dari solusi permasalahan yang didapat.

\section{Pembelajaran Berbasis Masalah (PBM)}

Pembelajaran berbasis masalah(PBM)adalah suatu strategiyang oleh Trianto disebut sebagai model pembelajaran yang dilandaskan pada berbagai masalah yang menuntutadanya penelitian sederhana atau penyelidikan yang mengharuskan penyelesaian secara empiris terhadap masalah-masalah tersebut. ${ }^{8}$ Pembelajaran berbasis masalah membantu peserta didik untuk mengembangkan keterampilan berpikir kritis dan keterampilan menyelesaikan masalah. Sedangkan M. Ibrahim dan M. Nur menyatakannya sebagai pendekatandalam pembelajaran. Strategi ini dikatakannya sebagai salah satu pendekatan pembelajaran yang tujukan untuk merangsang peserta didik berpikir tingkat tinggi di dalam sebuah situasi permasalahanyang nyata. ${ }^{9}$

\footnotetext{
${ }^{2}$ Ratumanan, Tanwey Gerson. 2002. Belajar dan Pembelajaran. Surabaya: UNESA University Press. Hal. 123

${ }^{3}$ E. Mulyasa. 2007. Kurikulum Tingkat Satuan Pendidikan. Bandung: PT Remaja Rosdakarya.Hal. 255

${ }^{4}$ Sugihartono. 2007. Psikologi Pendidikan. Yogyakarta: UNY Press.Hal. 81

${ }^{5}$ Trianto. 2010. Model Pembelajaran Terpadu. Jakarta: Bumi Aksara. Hal. 95

${ }^{6}$ Alec Fisher. 2009. Berpikir Kritis Suatu Pengantar. Jakarta: Erlangga.Hal. 2

${ }^{7}$ Ibid. Hal. 8

${ }^{8}$ Trianto. 2010. op.cit.Hal. 90

${ }^{9}$ Rusman.2012. op.cit.Hal. 241
}

Jurnal Socius: Journal of Sociology Research and Education Vol. 4, No.1, Th. 2017 
Pembelajaran berbasis masalah memiliki langkah-langkah yang jelas dalam melibatkan guru dan peserta didik untuk menyelesaikan permasalahan dalam pembelajaran. Menurut John Dewey ${ }^{10}$ ada tujuh langkah yang harus dilakukan dalam pelaksanaan strategi pembelajaran berdasarkan masalah (problem solving), yaitu sebagai berikut:

1) Merumuskan permasalahan, merupakan langkah pertama yang dilakukan peserta didik berupa penentuan masalah yang akan dipecahkan.

2) Menganalisis masalah, adalah langkah kedua peserta didik berupa peninjauan masalah untuk dikritisi berdasarkan anekai sudut pandang.

3) Merumuskan hipotesis, adalah langkah ketiga peserta didik dalam memecahkan masalah yang sudah ditentukan sebelumnya berdasarkan pengetahuan yang mereka miliki.

4) Mengumpulkan data, yaitu langkah keempat yang dilakukan peserta didik guna mendapatkan informasi dalam upaya memecahkan masalah.

5) Pengujian hipotesis, adalah langkah kelima yang dilakukan peserta didik menyusun kesimpulan berdasarkan hipotesis yang telah diajukan sebelumnya.

6) Merumuskan rekomendasi terhadap masalah yang dipecahkan, yaitu langkah keenam yang dilakukan peserta didik yang menggambarkan rumusan hasil penyelidikannya.

7) Menguji hipotesis yang sudah disusun dan merumuskan kesimpulan.

Jika diterapkan ke dalam kegiatan pembelajaran, maka langkah-langkah di atas dapat disusun sebagai berikut:

\section{Tabel 2. Penerapan Langkah-Langkah Pembelajaran Berbasis Masalah}

\begin{tabular}{cll}
\hline Tahap & Indikator Kerja & \multicolumn{1}{c}{ Kegiatan Guru } \\
\hline 1 & $\begin{array}{l}\text { Mengorientasi } \\
\text { peserta didik pada } \\
\text { masalah }\end{array}$ & $\begin{array}{l}\text { Menjelaskan tujuan pembelajaran yang akan dicapai, } \\
\text { menjelaskan logistik yang diperlukan, dan memotivasi } \\
\text { peserta didik agaraktifdalam pemecahan masalah. }\end{array}$ \\
\hline 2 & $\begin{array}{l}\text { Mengorganisasi } \\
\text { peserta didik untuk } \\
\text { belajar }\end{array}$ & $\begin{array}{l}\text { Membantu peserta didikmerumuskan dan mengatur } \\
\text { tugas-tugas belajar yang berkaitan dengan masalah } \\
\text { yang sudah ditetapkan untuk dipecahnya. }\end{array}$ \\
\hline 3 & $\begin{array}{l}\text { Penyelidikan atas } \\
\text { masalah }\end{array}$ & $\begin{array}{l}\text { Mendorong peserta didik mengumpulkan data } \\
\text { informasi yang guna memperoleh penjelasan } \\
\text { dalammemecahkan masalah. }\end{array}$ \\
\hline 4 & $\begin{array}{l}\text { Mengembangkan } \\
\text { dan menyajikan } \\
\text { hasil investigasi }\end{array}$ & $\begin{array}{l}\text { Membantu peserta didik dalam merencanakan dan } \\
\text { menyiapkan karya, serta membantu mereka untuk } \\
\text { saling berbagi tugas dengan temannya. }\end{array}$ \\
\hline $\begin{array}{l}\text { Menganalisis dan } \\
\text { mengevaluasi } \\
\text { proses pemecahan } \\
\text { masalah }\end{array}$ & $\begin{array}{l}\text { Membantu peserta didik melakukan analisis dan } \\
\text { telah merekalakukan. }\end{array}$ \\
\end{tabular}

\section{Metode Penelitian}

Penelitian yang dilakukan ini merupakan Penelitian Tindakan Kelas (PTK) yaitu, kegiatan mencermati terhadap aktivitas belajar peserta didik, berupa tindakan yang sengaja dimunculkan dan berlangsung dalam sebuah kelas secarakolektif. ${ }^{11}$ Penelitian tindakan kelas ini dilakukan secara kolaboratif dan partisipatoris. Dengan kata lain penelitian ini tidak dilakukan sendiri tetapi bekerja sama dengan guru sosiologi SMA Negeri 1 Pariaman.

\footnotetext{
${ }^{10}$ Wina Sanjaya. 2006. Strategi Pembelajaran Berorientasi Standar Proses Pendidikan. Jakarta: Kencana Prenada Media Group. Hal 217

${ }^{11}$ Suharsimi Arikunto. 2006. Penelitian Tindakan Kelas. Jakarta: BumiAksara. Hal. 3
} 
Penelitian ini dilakukan di kelas XI IPS 2 SMA Negeri 1 Pariaman. Waktu pelaksanaan penelitian ini yaitu pada semester dua atau genap tahun pelajaran 2016-2017. Subjek penelitian ini adalah peserta didik di kelas XI IPS 2 SMA Negeri 1 Pariaman yang berjumlah 32 siswa, laki-laki 11 orang dan perempuan 22 orang.

Penelitian yang dilakukan ini dirancang berdasarkan model penelitian tindakan kelas (PTK) yang sudah dibakukan dalam empat komponen kegiatan. Keempatnya merupakan alngkah-langkah kegiatan, mulai darimembuat perencanaan, melakuan tindakan, melaksanakan pengamatan, dan melakukan refleksi. Keempat komponen itu saling berhubungan sebagai sebuah sistem yang disebut siklus. ${ }^{12}$ Penelitian telah dilakukan sebayak dua sikulus

Pengumpulan data dilakukan melalui cara observasidengan menggunakan lembar observasi pembelajaran yang terdiri dari lembar pengamatan proses pembelajaran dan lembar kegiatan siswa. Selain observasi peneliti juga mengumpulkan data melalui wawancara terhadap guru dan peserta didik dengan menggunakan alat berupa pedoman wawancara.

Setelah data terkumpul, lalu peneliti analisis guna mengetahui tingkat kemampuan berpikir kritis peserta didik kisi-kisi yang sudah dituangkan ke dalam lembar observasi. Untuk mengetahui hal di atas peneliti terlebih dahulu menghitung frekuensi peserta didik yang menunjukkan berfikir secara kritis melalui dua siklus kegiatan.

Adapun cara yang peneliti gunaka untuk menghitung peserta didik yang berfikir kritis tersebut adalah menggunakan rumus perhitungan berupa persentase berikut ini:

$P=\frac{F}{N} \times 100 \%$

Keterangan:

$\mathrm{P}=$ presentase berpikir kritis siswa

$\mathrm{F}=$ jumlah siswa yang memenuhi aspek berpikir kritis indikator tertentu

$\mathrm{N} \quad=$ jumlah seluruh siswa

$\% \quad=$ persentase

Hasil perhitungan yang sudah didapat seterusnya peneliti masukkan ke dalam kategori tingkatan kemampuan. Pengkategorian dimaksudkan mengetahui sebaran kualifikasi kemampuan berpikir kritis peserta didik. Cara pengkategorian tersebut terlihat di bawah ini.

Tabel 3. Kriteria Kemampuan Berpikir Kritis Siswa

\begin{tabular}{ll}
\hline Presentase (\%) & Kriteria \\
\hline $81 \%-100 \%$ & Sangat Baik \\
\hline $61 \%-80 \%$ & Baik \\
\hline $41 \%-60 \%$ & Cukup \\
\hline $21 \%-40 \%$ & Rendah \\
\hline $0 \%-20 \%$ & Sangat Rendah \\
\hline
\end{tabular}

\footnotetext{
${ }^{12}$ Wijaya Kusumah dan Dedi Dwigatama. 2012. Mengenal Penelitian Tindakan Kelas. Edisi Kedua. Jakarta: PT Indeks. Hal. 27
}

Jurnal Socins: Journal of Sociology Research and Education Vol. 4, No.1, Th. 2017 
Target kemampuan berpikir kritis yang diharapkan pada penelitian ini adalah kriteria Baik yakni pada interval $61 \%$ ke atas. Hasil analisis data penelitian ini disajikan secara deskriptif atau melalui sebuah penggambaran tertulis yang berisi kualivikasi kemempuar berfikir kritis peserta didik dan proses pembelejaran yang mereka lalui sesuai dengan peneliti rancang.

\section{Hasil Penelitian dan Pembahasan}

Penelitian dimulai dengan pengumpulan data kemampuan berfikir kritis peserta didik tahap pra tindakan atau sebelum diberikan tindakan. Pada tahap pra tindakan kemampuan berfifkir kritis peserta didik masih sangat rendah. Setelah dilakukan tindakan, maka terjadi peningkatan, namun masih berada dalam kategori rendah. Rendahnya kemampuan berfikir peserta didik pada siklus I dikarenakan langkah-langkah dalam model pembelajaran berbasis masalah belum terlaksana dengan maksimal.

Setelah dilakukan perbaikan pada pembelajaran siklus II, maka terjadi peningkatan. Indikator yang mengalami peningkatan paling tinggi yaitu mengidentifikasi pokok masalah mencapai $75 \%$, meningkat 51,525\% dari siklus I 23,475\%, pada indikator mengemukakan pendapat, menentukan solusi permasalahan dan mengemukakan solusi mencapai $71,26 \%$, meningkat $38,573 \%$ dari hasil penelitian siklus I yaitu $32,687 \%$, pada indikator memberikan pertanyaan kritis mengalami peningkatan yaitu $51,66 \%$, meningkat $29,785 \%$ dari siklus satu yaitu $21,875 \%$, dan pada indikator mengemukan kesimpulan solusi mengalami peningkatan, namun tida begitu signifikan yaitu 27,185, meningkat 8,993\% dari siklus I $18,187 \%$. Peningkatan tipa-tiap indikator berpikir kritis peserta didikterlihat pada tabel berikut ini:

Tabel 4. Perbandingan Kemampuan Berpikir Kritis Tahap Pra Tindakan, Siklus I an Siklus II Kelas XI IPS 2 SMAN 1 Pariaman

\begin{tabular}{|c|c|c|c|c|c|c|}
\hline \multirow{3}{*}{ No } & \multirow{3}{*}{$\begin{array}{c}\text { Kemampuan Berpikir } \\
\text { Krtitis Siswa }\end{array}$} & \multirow{2}{*}{$\begin{array}{c}\text { Pra } \\
\text { Tindakan }\end{array}$} & \multicolumn{2}{|c|}{ Siklus I } & \multicolumn{2}{|c|}{ Siklus II } \\
\hline & & & $\begin{array}{c}\text { Pertemuan } \\
1\end{array}$ & $\begin{array}{l}\text { Pertemuan } \\
\quad 2\end{array}$ & $\begin{array}{c}\text { Pertemuan } \\
3\end{array}$ & $\begin{array}{c}\text { Pertemuan } \\
4\end{array}$ \\
\hline & & $\%$ & $\%$ & $\%$ & $\%$ & $\%$ \\
\hline 1 & $\begin{array}{l}\text { Mengidentifikasi pokok } \\
\text { masalah }\end{array}$ & $16,6 \%$ & $19,35 \%$ & $28,12 \%$ & $70 \%$ & $72,41 \%$ \\
\hline 2 & $\begin{array}{l}\text { Memberikan pertanyaan } \\
\text { secara tepat (pertanyaan } \\
\text { kritis) }\end{array}$ & $13,3 \%$ & $19,35 \%$ & $34,75 \%$ & $36.66 \%$ & $55,17 \%$ \\
\hline 3 & Mengemukakan pendapat & $10 \%$ & $22,58 \%$ & $37,5 \%$ & $63,33 \%$ & $72,41 \%$ \\
\hline 4 & $\begin{array}{l}\text { Menentukan solusi } \\
\text { permasalahan }\end{array}$ & $10 \%$ & $25,80 \%$ & $43,75 \%$ & $66,66 \%$ & $75,86 \%$ \\
\hline 5 & $\begin{array}{l}\text { Mengemukakan solusi } \\
\text { dari permasalahan }\end{array}$ & $10 \%$ & $25,80 \%$ & $43,75 \%$ & $66,66 \%$ & $75,86 \%$ \\
\hline 6 & $\begin{array}{l}\text { Menentukan kesimpulan } \\
\text { dari solusi permasalahan }\end{array}$ & $3 \%$ & $13,33 \%$ & $21,87 \%$ & $23,33 \%$ & $31,03 \%$ \\
\hline
\end{tabular}

Sumber : Olahan hasil observasi, 2017

Berdasarkan tabel di atas terlihat bahwa pembelajaran sosiologi dengan menggunakan pembelajaran berbasis masalah belum secara signifikan memperlihatkan peningkatan kemampuan berfikir peserta didik. Kemampuan berpikir kritis dalam mengajukan pertanyaan yang berkaitan dengan permasalahan masih rendah bila dibandingkan dengan kegiatan lainnya. Siswa masih jarang sekali bertanya pada guru setelah guru memberikan apersepsi. 
Hal tersebut dikarenakan pada pembelajaran sebelumnya guru langsung menyampaikan topik permasalahan atau materi yang akan dibahas tanpa melakukan apersepsi, sehingga siswa jarang memiliki pertanyaan-pertanyaan dalam dirinya tentang permasalahan yang dibahas.

Pada siklus I ini guru mengaku belum terbiasa melakukan pembelajaran dengan PBM, sehingga masih ada beberapa langkah dalam pembelajaran yang lupa dilaksanakan walau pun sudah pernah diberikan pelatihan. Alasan lain yang melatarbelakangi hal tersebut adalah guru kurang dapat membina suasana yang responsif dalam menyampaikan apersepsi pada siklus I, sehingga sulit dicapai adanya timbal balik dari siswa.

Kemampuan berpikir kritis yang juga masih dalam kategori rendah adalah tahap menarik kesimpulan. Hal ini dikarenakan saat siswa memiliki jawaban berbeda guru kurang dapat meluruskan jawaban siswa dengan memberikan penjelasan lanjut, sehingga kesimpulan yang didapatkan siswa sebatas jawaban yang benar saja. Guru harus mampu mengantarkan siswa untuk merumuskan kesimpulan yang tepat.

Pada siklus II terjadi peningkatan.. Peningkatan yang paing tinggi yaitu pada indikator pertama mengidentifikasi pokok masalah $75 \%$, kemudian indikator menentukan solusi permasalahan 71,26\%, indikator Mengemukakan solusi dari permasalahan 71,26\%, dan indikator mengemukakan pendapat $67.87 \%$. Pada tiga indikator ini sudah tercapai kemampuan berpikir kritis siswa karena termasuk dalam kategori baik.

Kemudian ada dua indikator berpikir kritis yang belum tercapai yaitu memberikan pertanyaan secara tepat (pertanyaan kritis) 51,66 \%, guru belum mampu memancing siswa untuk bertanya hal ini dikarenankan oleh media atau sumber belajar yang digunakan guru belum mampu untuk memancing siswa bertanya terkait dengan materi pelajaran yang disampaikan. Kemudian pada indikator menentukan kesimpulan dari solusi permasalahan $27,18 \%$ hal ini dikarena kan guru juga belum mampu mengantarkan siswa bagaimana merangkum hasil dari diskusi saat presentasi kelompok sehingga siswa tidak bisa memberikan kesimpulan dari yang tepat, kesimpulan yang disampaikan oleh siswa terkadang hanya mengulang dari apa yang telah disampaikan sebelumnya belum merupakan rangkuman dari hasil diskusi kelas.

Kemampuan menarik kesimpulan peserta didik juga mengalami peningkatan walaupun belum mencapai kategori baik.. Hal ini bahwa secara umum berarti telah terjadi peningkatan kemampuan berfikir kritis peserta didik dalam pemebelajaran sossiologi melalui pembelajaran berbasis masalah.

Terjadinya peningkatan kemampuan di atas sangat berkaitan dengan kemampuan peserta didik membangun pengetahuan berdasarkan pengetahuan dan pengalamannya. Hal ini sesuai dengan prinsip belajar berdasarkan Teori Konstruktivisme yang merupakan sebuah teori yang menjelaskan perspektif laintentang seseorang belajar atau memperoleh pengetahuan. Menurut ahli teori ini, belajar yang dilakukan seseorang bukanlah melalui tranfer pengetahuan dari orang lain kepadanya, melainkan yang bersangkutan berusaha sendiri membentuk atau membangun pengetahuannya berdasarkan apa yang dilihat dan dirasakan. Oleh karena itu pengetahuan yang dimilikinya tidak akan selalu sepenuh sama dengan pengetahuan orang lain, meskipun objek yang dilihat sama.

Peserta didik telah bisa mengembangkan kemampuan berpikir dengan mengkonstruksikan pengetahuan. Hal ini terlihat ketika mereka sudah dapat mengemukakan pendapat disaat pembelajaran berlangsung. Mereka sudah bisa memahami permasalahan pembelajaran karena masalah yang disajikan merupakan permasalahan yang cukup dekat dengan kehidupan di sekitarnya. Bahkan peserta didik telah bisa menentukan dan mengungkapkan solusi permasalahan yang disajikan.

Pembelajaran berbasis masalah menjadi relevan untuk diterapkan sebagai strategi pembelajaran Sosiologi. Hubungan antara pembelajaran berbasis masalah dengan kemampuan berpikir kritis adalah berada pada langkah-langkah strategi pembelajaran 
tersebut yang mampu mengakomodasi kemampuan berpikir kritis peserta didik. Dengan pendekatan pembelajaran berbasis masalah disimpulkankan bahwa belajar Sosiologi menimbulkan daya tarik karena objek yang dipelajari merupakan kenyataan sosial yang dekat dan berada di dalam kehidupan peserta didik.

Selain itu, peserta didik yang dibelajarkan melalui strategi berbasis masalah membuat kemampuan berfikirnya menjadi menjadi lebih tinggi, dan dengan sendirinya akan mendorong keaktifan mereka selama belajar. Pembelajaran ini sangat berperan penting membantu peserta didikdalam memproses berbagai informasi yang sudah ada dalam benaknya sehingga mengarahkan dia merangkai pengetahuan mereka sendiri tentang dunia sosial dan sekitarnya. Dalam penelitian ini peneliti telah berhasil menerapkan model pembelajaran berbasis masalah dengan langkah-langkahnya sehingga dengan permasalahan yang disajikan oleh guru yang dekat dengan kehidupan peserta didik seperti mengkaji permasalahan masyarkat di Pantai Gondoriah, masyarakat di Pasar Pariaman dan masalahmasalah lain yang berada di sekitar siswa sehingga dapat meningkatkan kemampuan berpikir kritis peserta didik.

\section{Penutup}

Pelaksanaanpembelajaran sosiologi yang didasarkan pada masalah dapat meningkatkan kemampuan berpikir kritis peserta didik. Semua indikator mengalami peningkatan, namun belum semua mencapai kategori baik. Indikator yang mencapai kategori baik adalah kemampuan mengidentifikasi pokok masalah $75 \%$, kemudian indikator menentukan solusi permasalahan $71,26 \%$, indikator mengemukakan solusi dari permasalahan $71,26 \%$, dan indicator, danmengemukakan pendapat $67,87 \%$.

Adapun Indikator yang juga meningkat namun belum mencapai kategori baikadalah kemampuan memberikan pertanyaan secara tepat (pertanyaan kritis) 51,66\%, dan menentukan kesimpulan dari solusi permasalahan $27,18 \%$. Kedua indikator tersebut belum tercapai hal ini dikarenakan peneliti belum mampu menggunakan media atau sumber belajar yang baik yang dapat memancing siswa untuk bertanya. Kemudian peneliti juga belum mampu untuk membimbing siswa untuk menyimpulkan hasil dari pembelajaran.

\section{Daftar Pustaka}

Alec Fisher. (2009). Berpikir Kritis Suatu Pengantar. Jakarta: Erlangga.

E. Mulyasa. (2007). Kurikulum Tingkat Satuan Pendidikan. Bandung: PT Remaja Rosdakarya.

Fahrudin Faiz. (2012). Thinking Skills Pengantar Menuju Berpikir Kritis. Yogyakarta: Suka Press.

Hamzah B Uno, dkk. (2010). Desain Pembelajaran. Bandung: Publishing.

M. Ibrahim dan M. Nur. (2000). Pembelajaran Kooperatif. Surabaya: University Press.

Isjoni dan Arif Ismail. (2008). Model-Model Pembelajaran Mutakhir. Yogyakarta: Pustaka Pelajar.

Jogiyanto. (2006). Pembelajaran Metode Kasus. Yogyakarta: Andi.

Johnson. Elaine B. (2009). Contextual Teaching And Learning. (Edisi Terjemahan Ibnu Setiawan). Bandung: MLC.

Nana Sudjana.(1989). Penilaian Hasil Proses Belajar Mengajar. Bandung: PT Remaja Rosdakarya. 
Ratumanan, Tanwey Gerson. (2002). Belajar dan Pembelajaran. Surabaya: UNESA University Press.

Sugihartono. (2007). Psikologi Pendidikan. Yogyakarta: UNY Press.

Rusman. (2012). Model-Model Pembelajaran: Mengembangkan Profesionalisme Guru. Jakarta: PT RajaGrafindo Persada.

Suharsimi Arikunto. (2006). Penelitian Tindakan Kelas. Jakarta: Bumi Aksara.

Suharsimi Arikunto. (2007). Penelitian Tindakan Kelas. Jakarta: Bumi Aksara.

Suharsimi Arikunto. (2012). Penelitian Tindakan Kelas. Jakarta: PT Bumi Aksara.

Suharsimi Arikunto. (2010). Prosedur Penelitian - Suatu Pendekatan Praktik (Edisi Revisi 2010). Jakarta: PT Rineka Cipta.

Slameto. (1996). Teknik Evaluasi Pendidikan. Jakarta: PT Raja Grafindo Persada.

Suyono dan Harianto. (2011). Belajar dan Pembelajaran Teori dan Konsep Dasar. Bandung: PT Remaja Rosdakarya

Trianto.(2009). Mendesain Model Pembelajaran Inovatif-Progresif. Surabaya: Kencana.

Trianto. (2010). Model Pembelajaran Terpadu. Jakarta: Bumi Aksara.

Wina Sanjaya. (2006). Strategi Pembelajaran Berorientasi Standar Proses Pendidikan. Jakarta: Kencana Prenada Media Group.

Wisadirana. (2004). Sosiologi Pedesaan. Malang: UMM Press 